\title{
Fesoterodine Fumarate
}

National Cancer Institute

\section{Source}

National Cancer Institute. Fesoterodine Fumarate. NCI Thesaurus. Code C72779.

The fumarate salt form of fesoterodine, a competitive muscarinic receptor antagonist

with muscle relaxant and urinary antispasmodic properties. Fesoterodine is rapidly

hydrolyzed in vivo into its active metabolite 5-hydroxy methyl tolterodine, which binds and inhibits muscarinic receptors on the bladder detrusor muscle, thereby preventing bladder contractions or spasms caused by acetylcholine. This results in the relaxation of bladder smooth muscle and greater bladder capacity, in addition to a reduction in involuntary muscle contractions and involuntary loss of urine. The active metabolite does not interact with alpha-adrenergic, serotonergic, histaminergic and excitatory amino acid receptors and is eliminated via renal excretion. 